\title{
The Image of the Female Nurse in Medication Advertisements in Brazil (1916 - 1931)
}

\author{
Imagem da Enfermeira nas Publicidades de Remédios no Brasil (1916 - 1931) \\ Imagen de La Enfermera en Anuncios de Medicamentos en Brasil (1916 - 1931) \\ Keythluci Faria Trigueiro da Silva*; Débora de Oliveira Villela**; Lisandra Risi***; \\ Juliane Aguiar Rocha***; Fernando Porto*****
}

\begin{abstract}
Background: The image of the female nurse has been discussed within the field of the history of the profession. It became evident that the attributes used by the nurses were determined by the professional education institutions in Brazil.

Objectives: To present and compare the frequency of the female images with the personal attributes of the female nurse in medication advertisements; and to comment on their decoding as a strategy to build the public image of the female nurse.

Methodology: This is a historical serial study, in which the images found were analysed through an analysis matrix. Results: During the study, 14 advertisements were found, of which 248 images featured in Fon-Fon magazine.

Conclusion: The representations of personal attributes in advertisements help to identify the competition between Nursing Schools regarding the diseemination of the public image of the female nurse.
\end{abstract}

Keywords: History of Nursing; nursing; image

\section{Resumo}

Enquadramento: A imagem da enfermeira tem vindo a ser discutida dentro do campo da história da profissão. Evidenciou-se que os atributos usados por essas profissionais foram determinados pelas instituições de ensino profissional no Brasil. Objetivos: Apresentar e articular a frequência das imagens femininas com atributos pessoais da enfermeira nas e com as publicidades de remédios; e comentar a sua decodificação como estratégia de contribuição para construção da imagem pública da enfermeira.

Metodologia: Pesquisa de natureza histórico serial, em que as imagens encontradas foram analisadas, aplicando-se uma matriz de análise.

Resultados: No período de estudo foram encontradas 14 publicidades, das quais 248 veiculações tiveram frequência na Revista Fon-Fon.

Conclusão: As representações dos atributos pessoais nas publicidades contribuem para identificar a concorrência entre Escolas de Enfermagem para enunciação da imagem pública da enfermeira.

Palavras-chave: História da Enfermagem; enfermagem; imagem

\footnotetext{
* Nursing student, Federal University of the State of the Rio de Janeiro, 22290-240, Rio de Janeiro, Brazi [keythlucifaria@gmail.com]. Contribution to the article: Bibliographic review. Address for correspondence Rua Moranga 547 Casa 63-Campo Grande, Rio de Janeiro, 23059-150, Brazil.

** Bacharelato, Nursing. RN, Clínica da Família Felippe Cardoso, Av. Nossa Sra. da Penha, 42 - Penha, - RJ CEP 21070-390.Rio de Janeiro, Brazil [debora.ovillela@gmail.com]. Contribution to the article: Collection

of images and circumstantial data. Brazil. [lisandrarisi@gmail.com]. Contribution to the article: Translation and revision of the Portuguese

language. [juliane_ar@globo.com]. Contribution to the article: Revision of the norms and application of the dat in the analysis matrix.

****** Postgraduate Degree, Nursing. RN, Professor, Federal University of the State of the Rio de Janeiro Department of Maternal-Child Nursing, Federal University of the State of the Rio de Janeiro, 22290-240, Rio de Janeiro, Brazil [ramosporto@openlink.com.br]. Contribution to the article: Article supervisor.
}

\section{Resumen}

Marco contextual: La imagen de la enfermera se ha discutido dentro del campo de la historia de la profesión. Se demostró que los atributos utilizados por esas profesionales fueron determinados por las instituciones de educación profesional en Brasil.

Objetivos: Presentar y articular la frecuencia de las imágenes femeninas con atributos personales de la enfermera en los y con los anuncios de medicamentos y analizar su decodificación como una estrategia de contribución para la construcción de la imagen pública de la enfermera.

Metodología: Investigación de naturaleza histórica y serial en la que las imágenes encontradas se analizaron mediante la aplicación de una matriz de análisis.

Resultados: Durante el período de estudio se encontraron 14 anuncios, de los cuales 248 colocaciones se presentaron en la revista Fon-Fon.

Conclusión: Las representaciones de los atributos personales en los anuncios contribuyen a identificar la competencia entre las escuelas de enfermería para enunciar la imagen pública de la enfermera.

Palabras clave: Historia de la enfermería; enfermería; imagen

Received for publication: 23.08 .15

Accepted for publication: 30.11 .15 


\section{Introduction}

The object of study is the female image, with personal attributes of female nurse, in medication advertisements in the illustrated press. The politicalsocial context in the period of 1916-1931 covered World War I, the Spanish flu epidemic, the Health Reform led by Carlos Chagas, the Commemorations of the 1st Centennial of the Independence of Brazil, the National Practitioners' Congress (1922), and the movement of the Brazilian female suffrage.

The objective of this study was to present and compare the frequency of the female images with personal attributes of the female nurse in medication advertisements; and comment on their decoding as a strategy to build the public image of the female nurse. This study aimed at advancing the studies on the public image of the female nurse, in order to understand the construction of their imagery process and professional identity.

The framework was provided by the socio-political context at the time, together with the process of professionalization of nursing in Brazil, particularly in schools and courses on female nurses' training in Rio de Janeiro: Escola Profissional de Enfermeiros e Enfermeiras (EPEE; 1890), current Escola de Enfermagem Alfredo Pinto; Escola Prática de Enfermeiras da Cruz Vermelha (1916); Curso de Enfermeira da Policlínica de Botafogo (1916); split of the EPEE in Escola Profissional de Enfermeiras Alfredo Pinto (1920); Curso de Enfermeiras da Assistência Particular de Nossa Senhora da Gloria (1920); Curso de Enfermeiros do Posto Central de Assistência (1920); Escola de Enfermeiras Municipais (1920); and Escola de Enfermeiras do Departamento Nacional de Saúde Pública (1922), current Anna Nery Nursing School (Carvalho, 2006; Porto \& Santos, 2008; Porto \& Amorim, 2010).

In Rio de Janeiro, at the time of the Federal District, various institutions were investing in the professionalization of nursing. At the time, among other magazines, two magazines stood out: Revista da Semana and Revista Fon-Fon. It was possible to identify, in their medication advertisements, images of women dressed in a similar way to the uniforms of female nurses shown in illustrated press.

Such advertisements have contributed to building the public image of the female nurse and possibly even to projecting women as female nurses, which is believed to have led many of them to enter the profession.

It should be highlighted that the word advertising is intended for commercial promotion, which seeks the consumption of goods or services. It is different from the word propaganda, which is considered to be a political, religious or ideological promotion (Marshall, 2003). Thus, the use of the term advertising in this study describes the dissemination of the consumption of medicines through the use of the female image with the attributes of female nurses. In this study, advertising images were analysed to question the influence of the personal attributes of the representations of female nurses as a way of contributing to the formation of the public image of the female nurse.

\section{Methodology}

The magazine selected was the Fon-Fon magazine. This choice was based on a survey carried out by the researcher Anna Maria de Souza Mauad-Andrade during the elaboration of her doctoral thesis (1991), who identified it as the most widely read of the four most important magazines at the time.

This magazine was published in the first half of the 20th century, in Rio de Janeiro. It spread the snobbery of the residents in Rio de Janeiro, was critical, published photographic instants, illustrations, literature and political and social cartoons at that time (Veraldo, 2011). The founding group was composed of Lima Campos, Gonzaga Duque and Mário Pederneiras who were renowned journalists and directed the magazine in 1907-1914; followed by Álvaro Moreyra and Hermes Fontes. The illustrators were Raul Calixto, José Carlos and Correia Dias until 1909, followed by Emílio Cardoso Aires and Nair de Tef (Zanon, 2009).

The study adopted the method of serial history and the analysis was conducted based on the microanalysis combined with semiotics. The latter was based on an analysis matrix, which allowed us to enter the universe of representations, identifying the influences and interrelationships of the mechanisms used by the social groups involved (Carvalho, 2006). The theoretical foundation for the analysis matrix used was Semiotics, namely the concepts of Pietroforte (2004, p.11):

[Expression plan is] the manifestation of that content in a system of verbal, non-verbal or syncretistic 
signification [and the content plan refers] to the meaning of the text, i.e., in semiotics terms, to what the text says and how it says what it says.

The analysis matrix was composed of four major items, with the same structure applied in previous studies of the research groups. The first item refers to image identification data, which includes the location of the collection, the name of the illustrated magazine, year of publication, copy number, page where the image was found and the date of publication of the magazine copy and title or headline of the image; the second item relates to the expression plan, which identifies the image credit, the text/image relationship, the image caption, the summary of the text, the type of photo, the format, the plan, the meaning and the location; the third item relates to the content plan, which includes the location, the people and the theme of the image being portrayed; and the last item refers to additional data obtained from other images, where the source of the information and the additional information are identified.
To identify the images, the expression facsimile was used. This is due to the fact they were previously printed in a means of communication, in this case the Fon-Fon Magazine, which can be found on the website of the National Library of Brazil.

As for the copyright information regarding the facsimiles used, the study complied with Law No. 9.610/1998 (Brasil, 1998). This law refers to the authorization, update and consolidation of the legislation on copyright and other aspects.

\section{Results and Discussion}

In the 148 editions searched, 14 types of medication advertisements with images were found, including personal attributes of female nurses in the Fon-Fon magazine, in the period from 1916 to 1931, in a total of 248 images with these attributes (Figure 1).

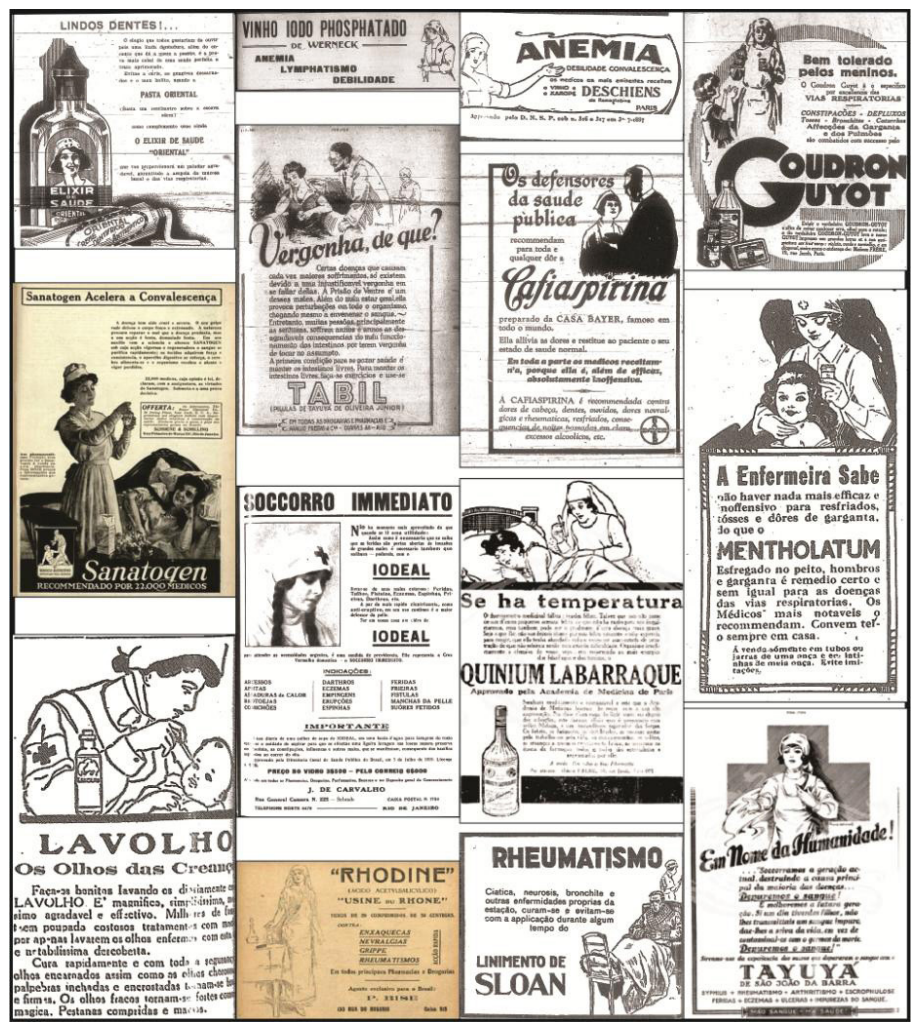

Figure 1. Medication advertisements with female images wearing female nurses' uniforms (1916-1931), featured in the pages of the Fon-Fon Magazine.

Source: Fon-Fon Magazine 


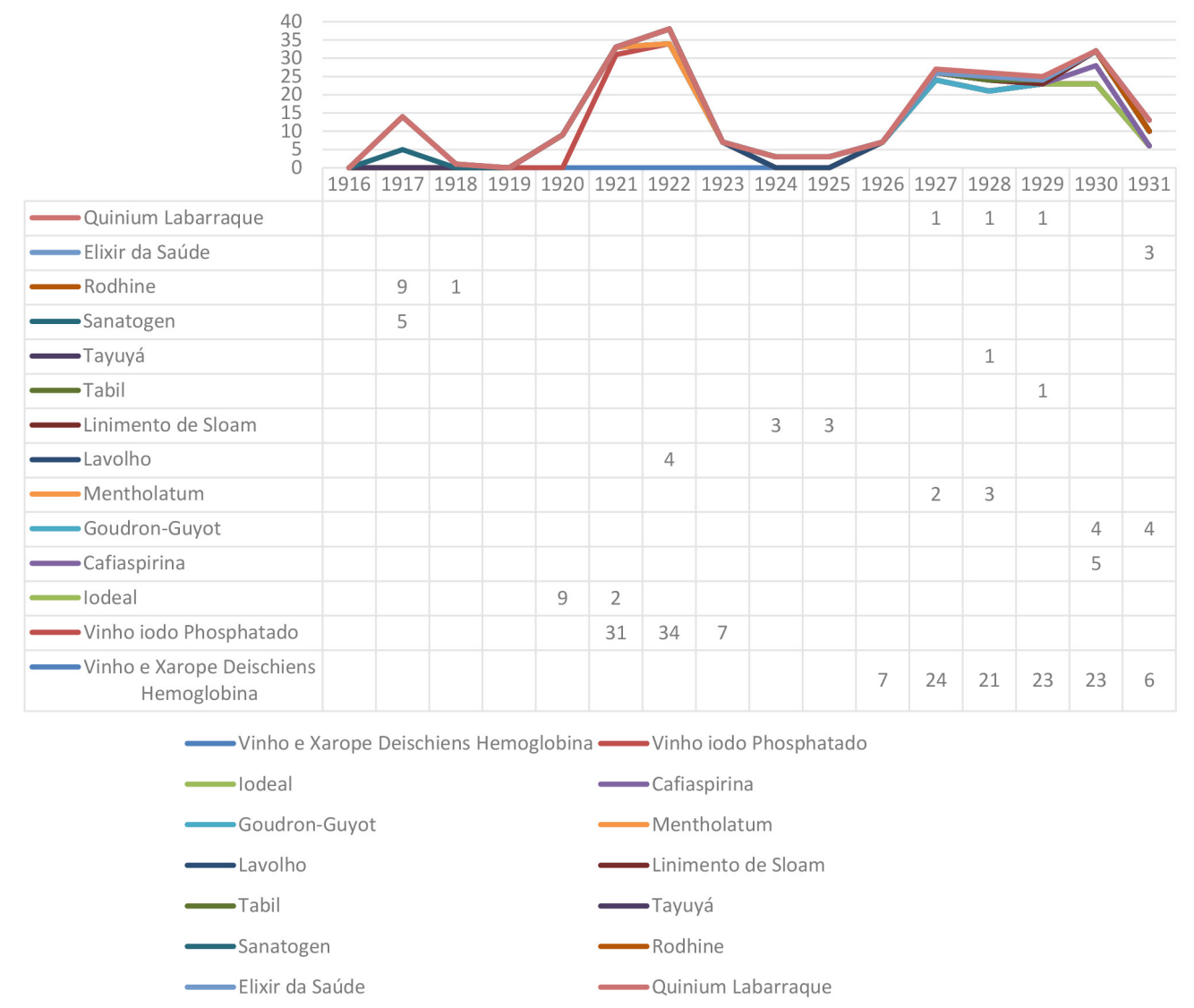

Figure 2. Frequency of the medication advertisements with female images wearing female nurses' uniforms (1916-1931), featured in the pages of the Fon-Fon Magazine.

The most common medication advertisements were about Vinho e Xarope Deischiens Hemoglobina (104), followed by Vinho iodo Phosphatado (72), Iodeal (11), Rodhine (10), Goudron Guyot (08), Linimento de Sloam (06), Cafiaspirina (05), Sanatogen (05), Mentholatum (05), Lavolho (04), Elixir da Saúde (03), Quinium Labarraque (03), Lysol (02), Tabil (01), and Tayuyá (01).

As shown in Figure 2, in 1916 and 1919, there was no occurrence of facsimiles. This is probably due to the participation of Brazil in World War I and to the Spanish flu. In 1917, Sanatogen (05) and Rodbine (09) emerged; in 1918, only Rodbine (01); in 1920, Iodeal (09); in 1921, Vinho iodo Pbosphatado (31) and Iodeal (02); in 1922, Vinho iodo Phosphatado (34) and Lavolho (04); in 1923, Vinho iodo Phosphatado (07); in 1924, Linimento de Sloam (03); in 1925, Linimento de Sloam (03); in 1926, Vinho e Xarope Deischiens Hemoglobina (07); in 1927, Vinho e Xarope Deischiens Hemoglobina (24), Quinium Labarraque
(01) and Mentholatum (02); in 1928, Vinho e Xarope Deischiens Hemoglobina (21), Quinium Labarraque (01), Tayuyá (01) and Mentholatum (03); in 1929, Vinho e Xarope Deischiens Hemoglobina (23), Quinium Labarraque (01) and Tabil (01); in 1930, Vinbo e Xarope Deischiens Hemoglobina (23), Cafiaspirina (05) and Goudron Guyot (04); and in 1931, Vinho e Xarope Deischiens Hemoglobina (06), Goudron Guyot (04) and Elixir da Saúde (03).

The personal attributes found in the facsimiles were: The veil, the cap, the bonnet and the symbol of the cross. These attributes worn by the female images were possibly generated by the social imaginary of imagery reproduction of symbolic elements of the female nurse's professional identification (Fonseca, 2011).

By decoding the attributes, we concluded that the veil can be considered as one of the ways to omit the identity of the person wearing it; the cap conveyed the meaning of the spirit of service, living with 
simplicity, being modest, loving everyone equally, being economical and generous; and the bonnet symbolized honour, distinction and responsibility (Porto \& Santos, 2010).

The light-coloured attributes - veil, bonnet and cap -, usually white, can be translated into meanings of purity, innocence, femininity, status, virtue and altruism, because it carries with it a virginal appeal and a symbol of dedication and trust (Fischer-Mirkin, 2001).

The female images with a veil in the advertisements were found in the medications Vinho iodo Phosphatado, Vinho e Xarope Deischiens Hemoglobina and Goudron Guyot, which appears to reflect a symbolic representation of the image of the aspirants and female nurses from the Escola Prática de Enfermeiras da Cruz Vermelha Brasileira. The advertisements about Iodeal, Lavolho, Mentholatum, Elixir da Saúde, showing what we believe to be the bonnet, are a symbolic representation of the Escola Profissional de Enfermeiros e Enfermeiras, slip in the Escola Profissional de Enfermeiras Alfredo Pinto. The advertisements about Lysol, Cafiaspirina, Linimento de Sloam and Tabil showed the cap, which was a symbolic representation of the Escola de Enfermeiras do Departamento Nacional de Saúde Pública (Porto \& Santos, 2010).

As regards the symbol of the Cross, the advertisements about the medications Vinho iodo Phosphatado, Iodeal, Vinho e Xarope Deischiens Hemoglobina, Mentholatum, Goudron Guyot and Elixir da Saúde reveal the image of the aspirants and female nurses graduated by the following education institutions: Escola Prática de Enfermeiras da Cruz Vermelha Brasileira and Escola Profissional de Enfermeiras Alfredo Pinto.

In this sense, the symbol of the cross was not exclusive of one particular education institution. The symbol of the cross was part of the uniforms of the aspirants and female nurses of the Escola Prática de Enfermeiras da Cruz Vermelha Brasileira, whose symbol was the red colour, and the Escola Profissional de Enfermeiras Alfredo Pinto, whose distinctive mark was the blue colour (Porto \& Santos, 2010).

The decoding of the personal attributes worn by the female images in the medication advertisements revealed the predominance of an education institution which promoted the professionalization of Nursing: the Escola Prática de Enfermeiras da Cruz Vermelha
Brasileira. However, the predominant presence of the symbol of the Cross cannot be highlighted because it is not possible to identify the colour of the geometric shape, which prevents a straightforward identification of one of the schools.

In view of the above, we can conclude that when the veil is combined with the symbol of the cross the colour used is red, whereas in the presence of the bonnet, the colour used is blue. This leads to the competition of distinction between the education institutions regarding their affirmation and the dissemination of the public image of the nurse as a strategy in the process of construction of this image. Figure 2 showed that the three most common advertisements in the selected magazine were about Vinho e Xarope Deischiens Hemoglobina, Iodeal and Vinho iodo Phosphatado. The advertisements of these products in the pages of the magazine used the image of a woman wearing a veil, light-coloured and longsleeved clothes, with the symbol of the cross on top of her head and on her chest. These attributes reming the image of the female nurse of the Escola Prática de Enfermeiras da Cruz Vermelha Brasileira (Rio de Janeiro) due to the similarities shown by the nursing professionals of that institution. The veil, associated with the symbol of the cross, was one of the symbols of the Red Cross, which considered the nurse as the messenger agent of the institutional principles of that school (Veraldo, 2011).

These personal attributes worked for the Red Cross as visual communication, where there was a consensus among the readers as to the symbolic belief advocated by the institution and, probably, the reliability of the product (Veraldo, 2011).

\section{Conclusion}

Based on our results, two main ideas should be highlighted: the symbolic elements used by the education institutions to promote the professionalization of nursing were in the interest of the medication advertising agencies, which probably showed the public image of the female nurse with the intention of making the consumer believe that the pharmaceutical product was reliable, because they were usually those who administered the medication. The images of the education institutions, each one with its symbolic distinctive mark, showed the 
competition between Nursing Schools/Courses with the objective of portraying, intentionally or not, the public image of the female nurse in the medication advertisement, which promotes the dispute for the construction of the public image of this health professional.

Therefore, we believe that this study has contributed to increase the knowledge about the construction of the public image of the female nurse, as well as to open other possibilities for future studies.

\section{References}

Lei no 9.610 de 19 de Fevereiro. (1998). Presidência da República, Brasília, Brasil. Retrieved from < http://www.planalto.gov. br/ccivil_03/leis/L9610.htm $>$.

Carvalho, A. C. (2006). Documentário: Aben (1926-1976). Rev. Bras. Enfer., 55(3) Brasilia, Brasil: Aben-Nacional.

Fischer-Mirkin, T. (2001). O código do vestir: Os significados ocultos da roupa feminina. Rio de Janeiro, Brasil: Rocco.

Fonseca, E. F. (2011). A imagem pública da enfermeira-parteira do hospital maternidade Pró-Matre do Rio de Janeiro no período de 1928-1931: (Des)construção de uma identidade profissional (Masters dissertation). Universidade Federal do Estado do Rio de Janeiro, Escola de Enfermagem Alfredo Pinto, Brasil.
Marshall, L. (2003). O jornalismo na era da publicidade. São Paulo, Brasil: Summus.

Pietroforte, A. V. (2004). Semiótica visual: Os percursos do olhar. São Paulo, Brasil: Contexto.

Porto, F., \& Amorim, W. (2010). Escolas e cursos de enfermagem na história da profissão no brasil (1890-1922). Revista Cultura de Los Cuidados, 14(27), 40-45.

doi:10.7184/cuid.2010.27.05

Porto, F., \& Santos, T. C. (2008). A enfermeira brasileira na mira do clique fotográfico (1919-1925). In: F. Porto \& W. Amorim (orgs.), História da enfermagem brasileira (Parte I, pp 2547). Rio de Janeiro, Brasil: Águia Dourada.

Porto, F., \& Santos, T. C. (2010). Propagandas de remédio na imprensa ilustrada e a imagem da enfermeira brasileira (1920-1925). Revista Escola de Enfermagem USP, 44(3), 819-26. Retrieved from http://www.scielo.br/scielo. php?script $=$ sci arttext\&pid $=$ S0080- 62342010000300038

Veraldo, T. X. (2011). A aparelbagem da imagem pública de enfermeiras na Revista Fon-Fon (1916-1931) (Degree final project). Universidade Federal do Estado do Rio de Janeiro, Escola de Enfermagem Alfredo Pinto, Brasil.

Zanon, M. C. (2009). A sociedade carioca da belle époque nas páginas do Fon-Fon.

Património e Memória, 4(2), 225-243. Retrieved from http://pem. assis.unesp.br/index.php/pem/article/view/178/510 